\title{
Experimental desiccation indicates high moisture content maintains hyporheic biofilm processes during drought in temperate intermittent streams
}

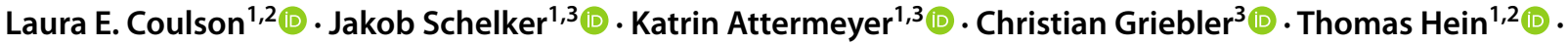 \\ Gabriele Weigelhofer ${ }^{1,2}$ (1)
}

Received: 3 November 2020 / Accepted: 18 March 2021 / Published online: 15 April 2021

(c) The Author(s) 2021

\begin{abstract}
Droughts are expected to become more common with climate change resulting in more frequent occurrences of flow intermittency in temperate streams. As intermittency has deleterious effects on fluvial microbial biofilms, there is a need to better understand how droughts affect the microbial functioning and thereby nutrient and organic matter processing in temperate stream ecosystems. Here, the hyporheic zone is of particular importance as it has been shown to be a hot spot for biogeochemical activity under flow intermittence. This study evaluates how drought duration affects microbial biofilm dynamics in the hyporheic zone of intermittent temperate streams. To do so, we used outdoor hyporheic flumes that were subject to periods of drought ranging from 4 to 105 days. Sediment was sampled before and during the drought, and at several occasions after rewetting. Samples were analyzed for extracellular enzymatic activity, bacterial respiration, and bacterial abundances including live to dead cell ratios. The high moisture content remaining in the hyporheic zone of the flumes allowed for the sustained microbial functioning during drought, regardless of drought duration. This can be attributed to cooler temperatures in these climate zones and shading by riparian forests. The high moisture content inhibited the local habitat and community changes that the biofilm might have undergone during more severe desiccation. However, the change in the hyporheic flow regime (flow cessation and resumption) may stimulate microbial processing in these moderate drought conditions. We suggest that the hyporheic zone may act as a buffer against drought and the factors determining this buffer capacity, such as sediment characteristics and climatic regions, need to be analyzed in more detail in future.
\end{abstract}

Keywords Intermittent $\cdot$ Biofilm $\cdot$ Hyporheic zone $\cdot$ Temperate climate $\cdot$ Microorganisms

\section{Introduction}

Despite their relatively small surface area, streams and rivers play a globally important role in the transformation and transport of organic matter (Allen and Pavelsky 2018; Drake

Laura E. Coulson

laura.coulson@wcl.ac.at

1 WasserCluster Lunz-Biologische Station, Dr. Carl Kupelwieser Promenade 5, 3293 Lunz am See, Austria

2 Institute of Hydrobiology and Aquatic Ecosystem Management, University of Natural Resources and Life Sciences (BOKU), Gregor-Mendel-Str. 33/DG, 1180 Vienna, Austria

3 Division of Limnology, Department of Functional and Evolutionary Ecology, University of Vienna, Althanstr. 14, 1090 Vienna, Austria et al. 2018). Microbial biofilms in streams are crucial in the biotic processing, storage, and release of organic matter and nutrients (Battin et al. 2016; Leff et al. 2016; Pusch et al. 1998). Stream biofilms inhabit a large surface area in the streambed as well as in the hyporheic zone and both interact significantly with solutes in the water passing through this interface (Battin et al. 2016; Boano et al. 2014). Therefore, these biofilms improve the water quality and contribute to the transformation of carbon compounds and the recycling of nutrients (Battin et al. 2008). However, desiccation of biofilms from increased droughts can effect biofilm communities and functioning (Colls et al. 2019; Sabater et al. 2016; Timoner et al. 2012).

Intermittent streams, or streams that periodically fall dry, are estimated to comprise more than $30 \%$ of the world's river length (Datry et al. 2017; Tooth 2000). As droughts are expected to become more common in the future with 
climate change (Dai 2013; IPCC 2013), it is also expected that the number and total length of intermittent streams will further increase (Larned et al. 2018; Sabater and Tockner 2009). While flow intermittency has commonly been studied in arid and semi-arid climates (Acuña et al. 2005; Datry et al. 2014; Timoner et al. 2012; others), studies on intermittent streams in temperate regions are rare (Arce et al. 2018; Marxsen et al. 2010; Oprei et al. 2019). This is of particular concern because the hydrological regime of many temperate catchments is also shifting due to climate change. Flow intermittency will likely become more common in these regions (Stubbington et al. 2017). For example, large areas of the northern Alps receive considerably less snow due to air temperature rise, resulting in decreased snowpacks and glacial retreat (Gobiet et al. 2014). These changes likely result in reduced groundwater recharge in spring and potentially lower summer flows in lotic environments. At the same time, extended summer droughts caused by low summer precipitation have been observed in Europe in recent years (Laaha et al. 2017; Oprei et al. 2019), highlighting the need to understand the effects of drought and flow intermittency in streams of temperate regions.

Intermittency of streams affects microbial biofilms in two ways: (1) local biofilm disturbance caused by desiccation during the drought phase, and (2) changes in transport patterns caused by the altered flow regime (i.e. flow cessation/resumption). Dynamics of biofilms on a local scale happen over time as the drought phase progresses, resulting in decreases in the moisture content and water availability, while sediment temperatures, oxygen availability, and salt concentrations may increase (Sabater et al. 2016). Drying and rewetting may reduce prokaryotic biomass as well as the fraction of viable and active cells and alter the composition of bacterial communities due to changes in the osmotic pressure and adaptions to dry conditions (Amalfitano et al. 2008; Gionchetta et al. 2019; Pohlon et al. 2013; Zoppini \& Marxsen, 2010). Transport pattern changes occur when water flow is stopped during drought and resumed after rewetting. A disruption in water flow decreases nutrient availability by reduced distribution of solutes, lowers microbial and algal mobility, and enables enhanced oxygen penetration into the hyporheic zone (Amalfitano et al. 2008; Cavanaugh et al. 2006; Dieterich and Anderson 1998; von Schiller et al. 2019; Zlatanović et al. 2018). Upon the return of water-saturated conditions, large amounts of fresh nutrients and organic matter become available to be transported to the biofilms again. Without doubt, changes in the flow regime, environmental conditions, and community composition during drying and rewetting, as described above, will seriously affect biogeochemical and microbial processes, such as organic matter mineralization, microbial respiration, and nutrient cycling (Acuña et al. 2015; Dahm et al. 2003; Timoner et al. 2012). Numerous studies have observed decreased enzymatic activities and respiration rates in river bed sediments during drought (Amalfitano et al. 2008; Gionchetta et al. 2019; Marxsen et al. 2010; Pohlon et al. 2013). However, there is evidence for a fast recovery of microbial activities from drought after rewetting, as exemplified by Marxsen et al. (2010) studying extracellular enzymatic activities (EEA) in stream biofilms.

To date, few studies have evaluated the impact of flow intermittency on hyporheic biofilms (Gionchetta et al. 2019). Microbial processing can differ between the surface and the hyporheic zone. The hyporheic zone can have high turnover rates of organic material and nutrients (Boulton et al. 1998; Danczak et al. 2016; McClain et al. 2003), especially during intermittency (Arias-Real et al. 2020; Burrows et al. 2017). As subsurface processes are inherently difficult to study (Boodoo et al. 2019), little is known about if and how hyporheic biofilms can sustain specific activities during prolonged no-flow conditions.

The aim of this study was to examine the effects of droughts on the functioning of hyporheic biofilms in streambed sediments, specifically pre-alpine gravel-bed streams characterized by coarse sediment grain sizes. As drought duration may act as an important control on biofilm resistance, we used outdoor hyporheic flume systems to experimentally simulate drought conditions of different durations. After a phase with normal flow, we allowed the stream sediments to dry at natural rates and with normal, seasonal temperature fluctuations. After 4, 8, 35, 70, and 105 days, the dried sediments were rewetted. The main research questions addressed were: (1) how does drying affect hyporheic biofilm processes in a temperate stream ecosystem and (2) how does drought duration influence the resistance of these processes to drying as well as their recovery after rewetting. We hypothesized that (1) microbial processing can be sustained during short droughts (days to a week), while it becomes significantly reduced during longer periods of drought (weeks to months), and (2) the period of recovery after desiccation will increase with increasing precedent drought duration.

\section{Methods}

\section{Experimental design and sample collection}

We conducted our drought experiment in six outdoor flumes that simulated the hyporheic zone of a gravel stream (5 m long, $0.6 \mathrm{~m}$ wide, $1.2 \mathrm{~m}$ deep) (Supp. Fig. 1). The flumes are located at the WasserCluster Lunz in Lunz am See, Austria in the eastern Alps $\left(47^{\circ} 15^{\prime} \mathrm{N}, 15^{\circ} 04^{\prime} \mathrm{E}\right)$. This prealpine area is primarily karstic and non-flow periods occur naturally during summer (May through September) and in cold winters (January through March). The average summer 
temperature in 2019 was $17.2^{\circ} \mathrm{C}$ and the average daily precipitation in the study summer was $6.7 \mathrm{~mm}$ per day.

The six flumes were filled with coarse gravel (average $25 \mathrm{~mm}$ in diameter) up to $60 \mathrm{~cm}$ depth. The gravel is natural fluvial gravel from an extended gravel bed of the Erlauf, a nearby river. During the pretreatment phase, the flumes were conditioned for one month with raw stream water from the Oberer Seebach, an adjacent pristine oligotrophic mountain stream (Fasching et al. 2016). Stream water was supplied to the flumes via PVC tubes from a header tank. Water was supplied to three depths: to the surface of the flumes, immediately below the sediment surface, and $10 \mathrm{~cm}$ below the sediment surface. The subsurface flow depths were supplied through nozzles installed at the designated depth on the side of the flume (see Supp. Fig. 1). Surface flow was approximately $62 \mathrm{ml}$ per hour. During the treatment phase, five of the flumes were allowed to fall dry by stopping all water inflow (in short, 'drought flumes' thereafter). These five flumes each experienced a different drought duration $(4,8,35,70$, and 105 days; one flume for each period). One flume remained permanently supplied with water similar to the pretreatment phase throughout the experiment to act as a control (in short, 'reference flume' thereafter). To maintain drought conditions, the flumes were protected from direct rainfall by a transparent plastic roof. In the rewetting phase, water flow was resumed in the drought flumes similar to the pretreatment phase. Temperature within the flumes was measured throughout the experiment with HOBO sensors (HOBO Pendant Temp/Light, Onset Computer Corporation, USA). We present the experimental design with all sampling events and in-flume temperature data in Supp. Fig. 2.

As our study aimed to evaluate microbial processes within the sediment during the ongoing experiment, we employed specifically designed sediment samplers that functioned as replaceable and reusable sediment cores. The cores consisted of perforated plastic tubes (PVC, $7.5 \mathrm{~cm}$ diameter, holes every $4 \mathrm{~cm}$ ) permanently installed in the sediment, which were filled with a screened sediment core (PVC, $3 \mathrm{~mm}$ ). In the core, sediment was placed in nylon mesh bags (grain size $<4.0 \mathrm{~mm}, \sim 100 \mathrm{ml}$ sediment per bag). The design allowed us to reduce disturbance during repeated sediment samplings by being able to remove the core and return it into the sediment. All sediment bags were allowed to colonize inside the cores for the entire pretreatment period.

For sampling, sediment bags were taken out of the drought flumes just before the initiation of drying, at the end of the drought period, and three times over the course of a week after rewetting ( $1 \mathrm{~h}, 1$ day, 7 days; in total 5 sampling dates for each drought flume). Sediment samples were collected at two different depths: upper hyporheic zone (5-30 $\mathrm{cm}$ below the sediment surface) and lower hyporheic zone (30-60 $\mathrm{cm}$ below the sediment surface). When individual sediment bags were removed for sampling from the desired depth, bags were replaced with a fresh sediment bag to provide a 'placeholder'. For each sampling event and drought flume, 5 replicates per sampling depth were taken from the original sediment bags (not the placeholders; in total 250 samples for all drought flumes). The reference flume was sampled more frequently to match the sampling of all the drought flumes, amounting to a total of 90 samples (9 dates). Sediments were brought to the lab within $2 \mathrm{~h}$ of sampling and immediately analyzed for extracellular enzymatic activity (EEA), bacterial respiration, bacterial viability, and moisture content. Samples for bacterial abundances ( $1 \mathrm{~g}$ sediment per sample) were fixed with formaldehyde (final concentration $2.5 \%$ ) and stored at $4{ }^{\circ} \mathrm{C}$ until analysis.

\section{Laboratory analyses}

EEA of $\beta$-D-1,4-glucosidase (Gluc), $\beta$-xylosidase (Xyl), phosphatase (Phos), and leucine-aminopeptidase (Pep) was measured in the sediments following the method described by Romani and Sabater (2001). In short, Gluc, $\mathrm{Xyl}$, and Phos were measured using 4-methylumbelliferyl (MUF)-substrates (MUF- $\beta$-D-glucopyranoside, MUF- $\beta$-Dxylopyranoside, and MUF-phosphate, respectively, SigmaAldrich, Germany) and Pep was measuring using a 7-amino4-methylcoumarin (AMC)- substrate (L-leucine-AMC, Sigma-Aldrich, Germany). For this, $1.0 \mathrm{~g}$ of sediment was suspended in $4 \mathrm{ml}$ sterile filtered stream water $(0.2 \mu \mathrm{m}$ pore size, polyethersulfone (PES)) and $120 \mu \mathrm{L}$ substrate (final concentration $0.3 \mathrm{mM})$ was added. Glycine buffer $(2 \mathrm{ml}, \mathrm{pH}$ 10.4) was added after $1 \mathrm{~h}$ to stop the reaction and fluorescence was measured with $365 / 455 \mathrm{~nm}$ excitation/emission wavelengths for the MUF-substrates and 380/440 excitation/emission wavelengths for the AMC-substrate on a platereader (Varioskan Flash, Thermo Fischer Scientific, Vaanta, Finland). In addition, moisture content of the sediment was determined by drying the sediment at $80{ }^{\circ} \mathrm{C}$ for $24 \mathrm{~h}$ and is expressed as percent water over dry weight. OM content was determined as ash free dry weight (AFDW) by drying the sediments at $400{ }^{\circ} \mathrm{C}$ for $4 \mathrm{~h}$ and is expressed as percent $\mathrm{OM}$ over dry weight.

Bacterial respiration was measured via $\mathrm{CO}_{2}$ production with the MicroResp ${ }^{\mathrm{TM}}$ system as described in the MicroResp technical manual (MicroResp ${ }^{\mathrm{TM}}$, James Hutton Ltd, Aberdeen, UK). For this, approximately $0.7 \mathrm{~g}$ of sediment were weighed into each well of a deep 96-well microplate ( 3 analytical replicates per sample) and incubated for $6 \mathrm{~h}$ at $25{ }^{\circ} \mathrm{C}$. The absorbance of the $\mathrm{CO}_{2}$ detection gel was measured using a spectrophotometric microplate reader (Varioskan Flash, Thermo Fischer Scientific, Vaanta, Finland) at $570 \mathrm{~nm}$. Furthermore, bacterial production was measured as bacterial protein production via ${ }^{3} \mathrm{H}$-leucine incorporation as described by Buessing and Gessner (2003). Briefly, $0.7-0.9 \mathrm{~g}$ were weighed into screw cap tubes, diluted with 
sterile filtered stream water, and incubated at a final concentration of $50 \mu \mathrm{mol} \mathrm{l}^{-1}{ }^{3} \mathrm{H}$-leucine for one hour at $15^{\circ} \mathrm{C}$ in the dark. One sample per bag and one blank for each flume were measured on a liquid scintillation counter (LS6500; Beckman Coulter, Fullerton, USA). Net disintegrations per minute were converted to pmol leucine $1^{-1}$ days $^{-1}$, and an isotope dilution factor of 2 was applied (Kirchman, 2001). Bacterial carbon production ( $\mu \mathrm{g} \mathrm{C}^{-1}$ days $^{-1}$ ) was calculated, using the conversion factor of 0.86 (Simon and Azam 1989).

Abundances of prokaryotes (herein referred to as bacterial abundances) were determined following the protocol of Duhamel and Jacquet (2006): after detachment from the sediment, samples were diluted 200 times, stained with SYBR Green II stain $(200 \times$ diluted in DMSO, Invitrogen Molecular Probes Inc., California, U.S.A.), and analyzed by flow cytometry (CytoFLEX, Beckman Coulter GmbH, Krefeld, Germany). Bacterial viability (percent viable cells) was determined using the Live/Dead bacterial viability kit (Invitrogen Molecular Probes, Inc., California, USA). Immediately after sampling, bacteria were separated from the sediment similar to the method described above. However, to avoid killing of cells during separation, sediment sonication was limited to $1 \mathrm{~min}$ on ice (Amalfitano et al. 2008).

\section{Data analysis}

Resistance is the 'persistence through time of an ecological system' (Grimm and Wissel 1997; Holling, 1973; Uehlinger 2000) and was used to evaluate the immediate impact of drought duration on biofilm activity (EEA, respiration, bacterial abundances and viability). This was done by calculating the percent change from the starting values to the values immediately after rewetting for each drought flume (Acuña et al. 2015). To evaluate whether response parameters were resistant to drought, changes in percent were compared to zero using one-tailed Mann-Whitney U test (Mann and Whitney 1947) with a Bonferroni correction for multiple comparisons (Dunn 1961). As there was no significant difference in any of the parameters (including moisture content) between the two hyporheic depths (ANOVA, $p<0.05$, $n=5$ ), data from different depths were pooled together for all analyses. Analyses was performed in R v.3.5.3 (R Core Development Team, 2020).

Due to the low number of sampling dates and the high temporal variability during recovery, we could not calculate the resilience of the parameters following Acuna et al. (2015). Instead, we explored potential post-drought effects one week after rewetting in each flume. As flumes significantly differed at the end of the pre-treatment period (one-way ANOVA, $\mathrm{p}<0.05, \mathrm{n}=10$ ), we analyzed each drought flume individually in comparison to the reference flume. Specifically, we evaluated the post-drought status by comparing the changes between pre-drought conditions and 7 days after rewetting ( $\Delta \mathrm{P}$ of the drought flume) with the changes in the reference flume during the same time period ( $\Delta \mathrm{P}$ of the reference flume) according to formula 1:

$\Delta P=A-B$

where $B$ is the average of the pretreatment values (in each respective flume), $A$ are the individual values 7 days after rewetting, and $\Delta P$ is the standardized value. This calculation was also done for the reference flume samples corresponding to the sampling event 7 days after rewetting in each of the drought flumes. We then used non-parametric pairwise Mann-Whitney $U$ tests to compare the standardized drought flume values to the associated standardized reference flume values (Mann and Whitney 1947) with a Bonferroni correction for multiple comparisons (Dunn 1961), also performed in R using the standard stats package. Results of the statistical analyses are reported in Table 1. This allowed us to attribute differences to the drought history of each drought flume, while the effects of seasonal variations and their interaction with drought duration were minimized. Additionally, any parameter development in the reference flume over the duration of the experiments may give insight into influencing factors apart from drying (e.g. seasonal temperature effects). The 7 days after rewetting sampling was selected for comparison in order to evaluate the medium-term effects of drought after flow resumption (as opposed to the immediate effects after $1 \mathrm{~h}$ ).

\section{Results}

All drought flumes fell dry during the treatment phase with significant decreases in sediment moisture content (Fig. 1). The moisture content was an average of $5.2 \pm 2.4 \%$ (of dry weight) at the end of each drought phase. Also, while there was no significant difference in the moisture content between the flumes, we observed a decreasing trend of moisture content in the flumes with longer drought periods, especially with those lasting for 70- and 105-days where the moisture content dropped to $4.9 \pm 2.4 \%$ and $3.9 \pm 1.8 \%$ at the end of the drought phase, respectively.

\section{Effects of drought length}

EEA was maintained throughout the drought phase for all drought lengths (Fig. 2a-d). Pep activities were higher at the end of the drought phase compared to both the predrought and post-drought activities (Fig. 2a). Phos activity levels were noticeably, though not significantly, higher for the drought and post-drought samples in the flume that experienced a 105-day drought compared to the other 
Table 1 Summary of statistical tests

Effects of drought length

Mann-Whitney $U$ Tests comparing the resistance to zero $(\mathrm{n}=10)$ with Bonferroni $\mathrm{p}$ value correction

\begin{tabular}{|c|c|c|c|c|c|c|c|c|c|c|}
\hline \multirow[t]{2}{*}{ Parameter } & \multicolumn{2}{|c|}{4 Days Dry } & \multicolumn{2}{|c|}{8 Days Dry } & \multicolumn{2}{|c|}{35 Days Dry } & \multicolumn{2}{|c|}{70 Days Dry } & \multicolumn{2}{|c|}{105 Days Dry } \\
\hline & $\mathrm{p}$ value & $\begin{array}{l}\text { test statis- } \\
\text { tic (U) }\end{array}$ & $\mathrm{p}$ value & $\begin{array}{l}\text { test statis- } \\
\text { tic }(\mathrm{U})\end{array}$ & $\mathrm{p}$ value & $\begin{array}{l}\text { test statis- } \\
\text { tic (U) }\end{array}$ & $\mathrm{p}$ value & $\begin{array}{l}\text { test statis- } \\
\text { tic (U) }\end{array}$ & $\mathrm{p}$ value & $\begin{array}{l}\text { test } \\
\text { statistic } \\
\text { (U) }\end{array}$ \\
\hline Aminopeptidase & 1.0 & 20 & 1.0 & 34 & 0.53 & 44 & 0.020 & 54 & 1.0 & 27 \\
\hline Glucosidase & 1.0 & 33 & 0.42 & 45 & 1.0 & 27 & 1.0 & 37 & 0.14 & 6 \\
\hline Xylosidase & 0.8 & 42 & 0.0098 & 55 & 0.53 & 44 & 0.65 & 43 & 1.0 & 28 \\
\hline Phosphatase & 0.098 & 50 & 0.32 & 9 & 0.029 & 2 & 0.049 & 52 & 0.020 & 54 \\
\hline Respiration & 0.0098 & 0 & 0.97 & 14 & 0.0098 & 55 & 0.0098 & 55 & 0.97 & 41 \\
\hline Bacterial Production & 1.0 & 11 & 0.5 & 0 & 1.0 & 0 & 1.0 & 9 & - & - \\
\hline Bacterial Abundances & 1.0 & 12 & 0.16 & 0 & 0.020 & 0 & 0.020 & 1.0 & 0.14 & 49 \\
\hline Bacterial viability & 0.0098 & 0 & 1.0 & 29 & 0.0098 & 54 & 0.0098 & 55 & 0.0098 & 0 \\
\hline
\end{tabular}

Effects of drought after rewetting

Mann-Whitney $U$ Tests comparing drought flume $(\mathrm{n}=10)$ to reference flume $(\mathrm{n}=6)$ with Bonferroni $\mathrm{p}$ value correction

\begin{tabular}{|c|c|c|c|c|c|c|c|c|c|c|}
\hline \multirow[t]{2}{*}{ Parameter } & \multicolumn{2}{|c|}{4 Days Dry-Ref } & \multicolumn{2}{|c|}{8 Days Dry-Ref } & \multicolumn{2}{|c|}{35 Days Dry-Ref } & \multicolumn{2}{|c|}{70 Days Dry—Ref } & \multicolumn{2}{|c|}{105 Days Dry-Ref } \\
\hline & $\mathrm{p}$ value & $\mathrm{U}$ & $\mathrm{p}$ value & $\mathrm{U}$ & $\mathrm{p}$ value & $\mathrm{U}$ & $\mathrm{p}$ value & $\mathrm{U}$ & $\mathrm{p}$ value & $\mathrm{U}$ \\
\hline Aminopeptidase & 1.0 & 380 & 1.0 & 80 & 0.0013 & 0 & 0.055 & 7 & 0.024 & 5 \\
\hline Glucosidase & 0.0034 & 0 & 0.0034 & 0 & 0.013 & 2 & 0.0020 & 0 & 0.0025 & 1 \\
\hline Xylosidase & 0.16 & 50 & 0.11 & 51 & 1.0 & 33 & 0.0020 & 54 & 0.038 & 6 \\
\hline Phosphatase & 1.0 & 39 & 0.0013 & 60 & 0.28 & 48 & 0.11 & 51 & 1.0 & 21 \\
\hline Respiration & 0.11 & 9 & 0.0013 & 0 & 1.0 & 27 & 0.37 & 13 & 0.0013 & 0 \\
\hline Bacterial Production & 0.4 & 0 & - & - & 0.76 & 2 & - & - & - & - \\
\hline Bacterial Abundances & 0.47 & 29 & 0.044 & 1 & 0.9 & 9 & 0.0013 & 60 & 0.0085 & 3 \\
\hline Bacterial viability & 0.014 & 51 & 0.37 & 47 & 0.0013 & 0 & 0.21 & 1 & 0.015 & 56 \\
\hline
\end{tabular}

Bold values indicate sigfnicant differences $(p>0.05)$

Fig. 1 The moisture content of all flumes that experienced drought across all sampling events. Different symbols indicate different flumes that experienced droughts of different lengths. Gray area indicates drought period. Symbols represent the mean values and bars the standard deviation

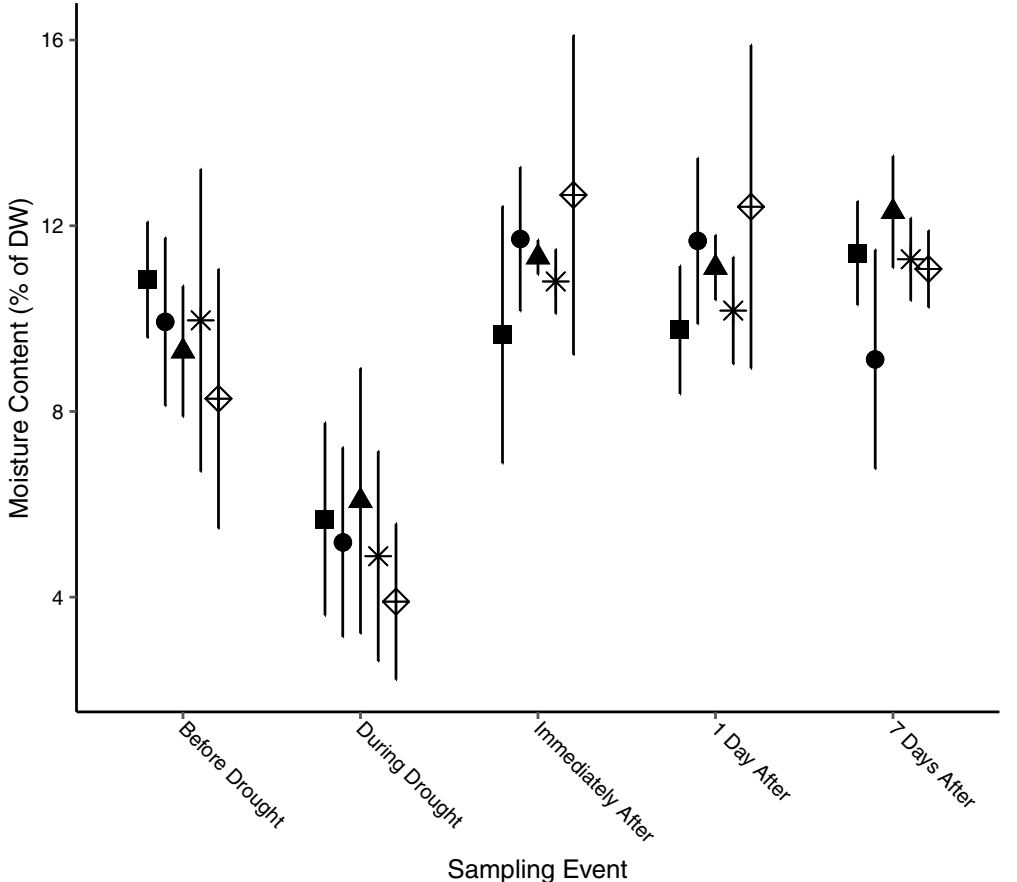

Sampling Event
4 Days Dry
- 8 Days Dry
- 35 Days Dry
* 70 Days Dry
$\oplus 105$ Days Dry 

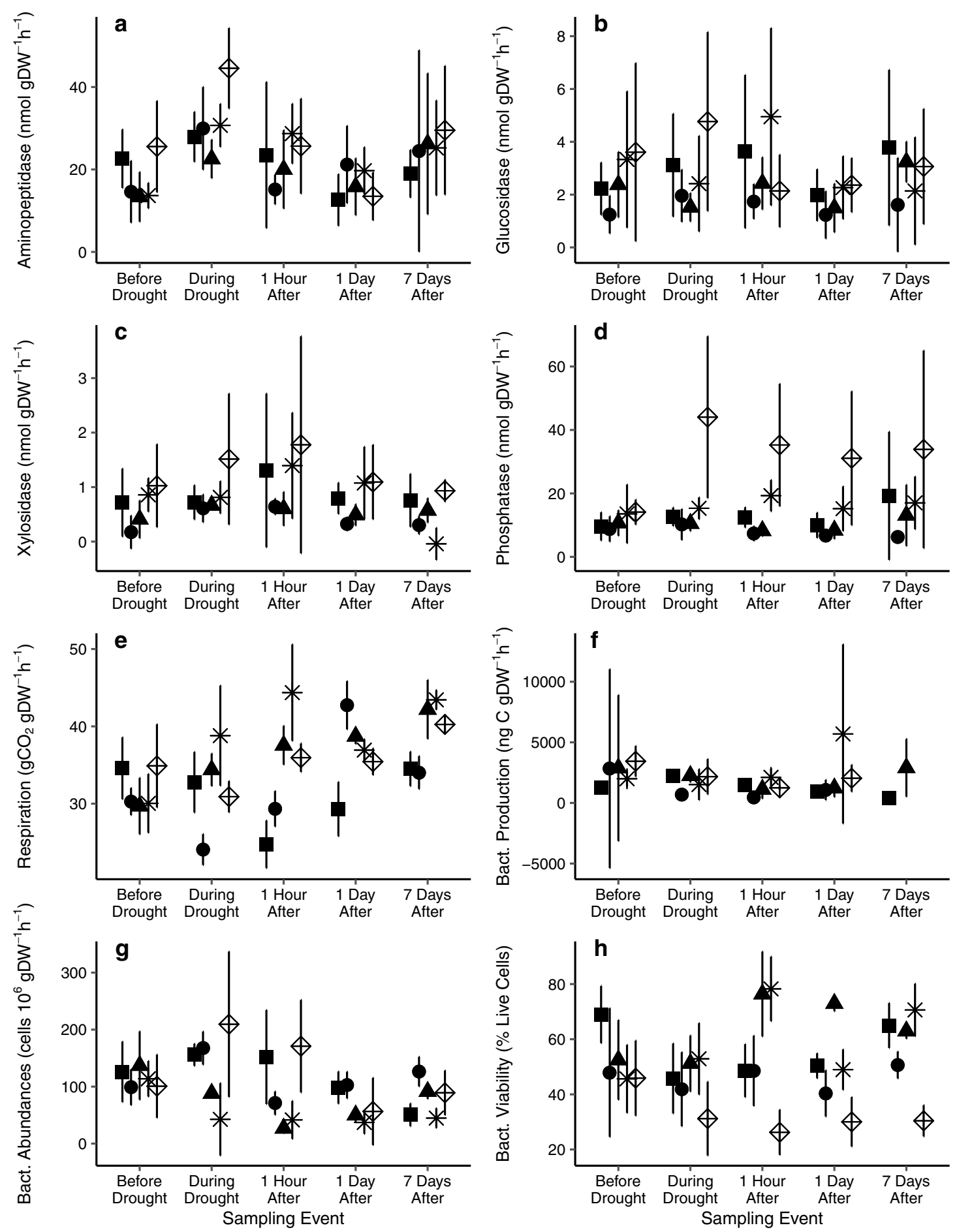

4 Days Dry

8 Days Dry

35 Days Dry $\quad$ * 70 Days Dry $\oplus 105$ Days Dry

Fig. 2 Parameters in all flumes that experienced drought across all sampling events. Different symbols indicate the mean of different flumes that experienced drought. Bars indicate standard deviation.
Non-visible bars are obscured by the symbol (i.e., small standard deviation). Gray area indicates drought period 
flumes (Fig. 2d). EEA were generally close to zero for all drought durations (Fig. 3a-d, Table 1). In some cases, EEA were significantly different from zero (Mann Whitney $U$ test, $\mathrm{p}<0.05, \mathrm{n}=10$; i.e. Xyl, 8-days, 105-days), however the absolute values for Xyl remain low and the fluctuation remains within expected seasonal variability.

Respiration rates did not show any clear pattern when comparing the averages of all drought flumes (Fig. 2e). However, rates tended to be lower at the end of the drought
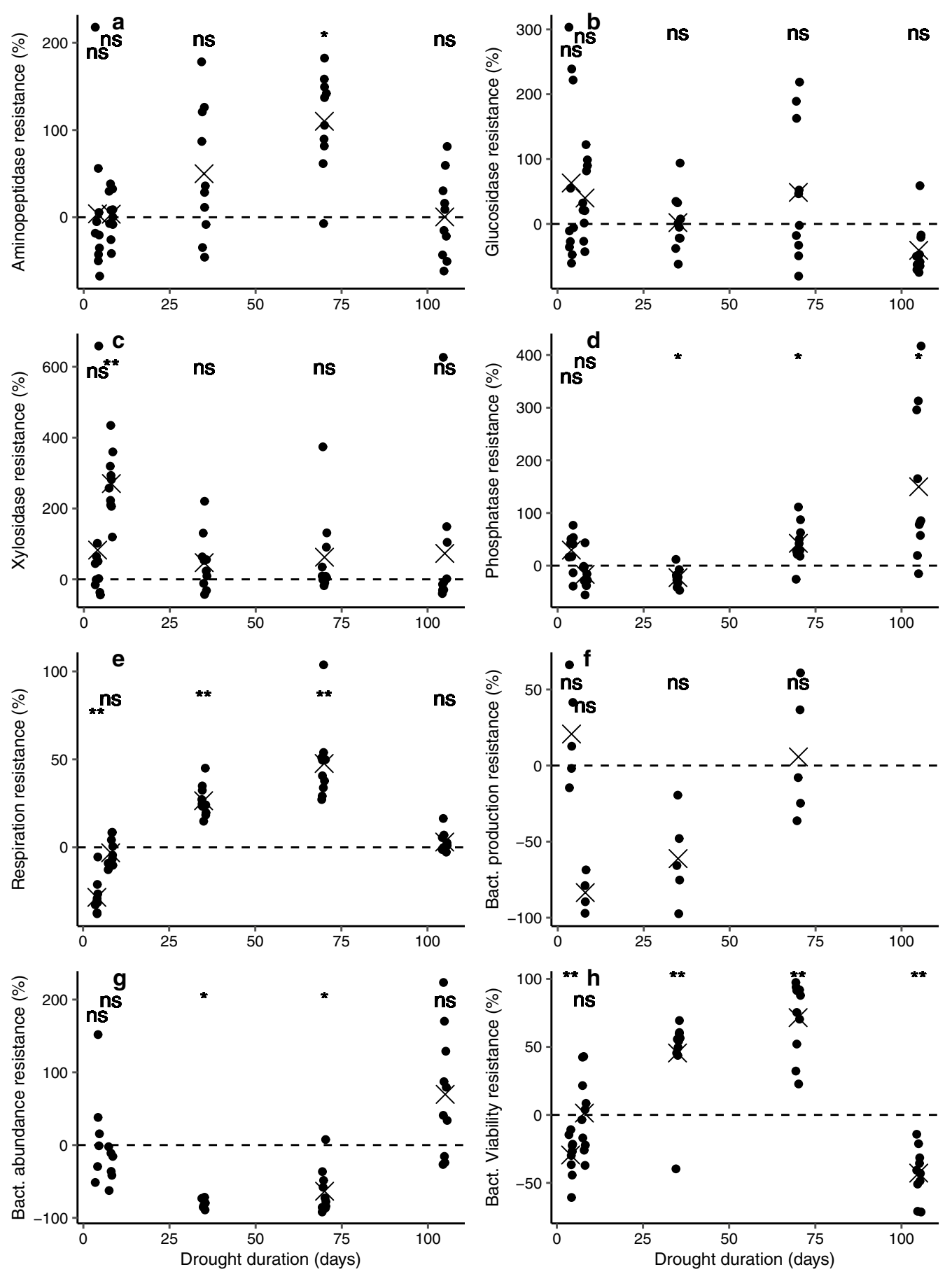

Fig. 3 Resistance of parameters for the different drought lengths. Dots indicate individual sampling points and " $X$ " indicates the resistance values of the specified drought flumes and zero ( $n s$ not significant, $* \mathrm{p} \leq 0.05, * * \mathrm{p} \leq 0.01, * * * \mathrm{p} \leq 0.001)$ 
period and/or shortly after rewetting in the flumes with short drought duration (4 days and 8 days), while values remained at the same level or even increased slightly during and after the drought in flumes with longer drought duration (35 days, 70 days, and 105 days). Aside from the flume that experienced a 4-day drought, respiration resistance values were also close to zero (Fig. 3e). While some resistance values were significantly different from zero (Mann Whitney $U$ test, $\mathrm{p}<0.05, \mathrm{n}=10$; 4-days, 35-days, and 70-days), the fluctuation was within $50 \%$ (Fig. 3e, Table 1).

Neither bacterial production (Fig. 2f) nor the abundance of bacterial cells (Fig. 2g) were impacted during the drought phase. However, resistance values for bacterial production were below zero for the flumes that experienced 8- and 35-day droughts, but were not significantly different (Fig. 3f, Table 1). Resistance values for bacterial abundances were significantly below zero in the flumes that experienced 35- and 70-day droughts (Mann Whitney $U$ test, $\mathrm{p}<0.05$; Fig. 3g, Table 1).

Bacterial viability showed no significant effect of the drought period (Fig. 2h). The percentage of viable cells increased immediately upon rewetting in all flumes, except for the flume that experienced a 105-day drought where the bacterial viability remained low even after rewetting. Resistance values for bacterial viability reflected a similar pattern to respiration, close to or above zero (Fig. 3h, Table 1). As with respiration, the values for 4-, 35-, 70-, and 105-days dry were significantly different from 0 (Mann Whitney $U$ test, $\mathrm{p}<0.05, \mathrm{n}=10$; Table 1), the fluctuation was within $50 \%$.

\section{Effects of drought after flow resumption}

After flow resumption, EEAs showed specific patterns in drought flumes that often deviated significantly from those in the reference flume (Fig. 4a-d). In general, Pep remained stable or slightly increased from pre-drought to post-drought in the drought flumes, while it decreased with time in the reference flume. Thus, we observed significant differences between the drought and reference flumes for 35- and 105day droughts (Mann-Whitney $U$ test, $\mathrm{p}<0.05, \mathrm{n}=10$ ). Gluc also did not change from pre-drought to post-drought in all of the drought flumes, while it showed a decrease in the reference flume, resulting in statistically significant differences between drought and reference samples (Mann-Whitney $U$ test, $\mathrm{p}<0.05, \mathrm{n}=10)$. Xyl indicated no change from pre-drought to post-drought levels in the drought flumes, except for a marked decrease in the flume that experienced a 70-day drought. In contrast, corresponding samples in the reference flume showed a slight increase in Xyl from pre-drought values, except for the 105-days sampling. Phos either remained stable or slightly increased between pre- and post-drought levels in all flumes (including the reference flume), except for the flume experiencing 8-days drought, where we observed a small decrease. In summary, we found no evidence for an influence of drought duration on postdrought EEAs in the hyporheic zone of our flumes.

Changes in respiration between pre- and post-drought samples demonstrated a seasonal pattern. In most drought flumes, respiration rates increased between pre- and postdrought conditions. However, the changes were more pronounced when the rewetting occurred in midsummer (flumes with droughts of 35- and 70-days) (Fig. 4e). The reference flume exhibited a similar seasonal pattern.

We observed a general decrease in bacterial production between pre- and post-drought samplings in all flumes, independent of drought duration (Fig. 4f). Changes in bacterial abundances between pre- and post-drought samples were variable and did not show any consistent patterns across flumes or with drought duration (Fig. $4 \mathrm{~g}$ ).

Bacterial viability showed a similar pattern to respiration in the drought flumes, with the increase between pre- and post-drought samples most pronounced during midsummer (Fig. 4h). However, the reference did not demonstrate this seasonal pattern as strongly and generally increased between pre- and post-drought samples.

\section{Discussion}

Stream biofilms are the primary sites for nutrient processing and carbon cycling in fluvial ecosystems (Battin et al. 2016; Leff et al. 2016; Pusch et al. 1998). Any alteration of microbial communities and their activities during, but more importantly, following droughts after rewetting would pose substantial alteration of the overall functioning of stream ecosystems (Vazquez et al. 2011; Ylla et al. 2010). However, contrary to our hypotheses, neither the hyporheic community nor microbial processes were significantly reduced during the drought phase in our study, independent of drought duration (hypothesis 1). Therefore, the period of recovery after desiccation also was not impacted by longer drought durations (hypothesis 2). We suggest that this lack of impact is due to the remaining moisture content in the hyporheic sediments during drought, which was sufficient to maintain microbial processes even during the longest drought (105 days). However, we also found that drying and rewetting can stimulate some microbial processes (such as glucosidase enzymatic activities) when flow resumes after a moderate drought.

\section{High moisture content prevents local biofilm changes during drought}

The high moisture content remaining in the hyporheic zone $(5.17 \pm 2.37 \%)$ during the drought phase allowed the microbial biofilm communities to sustain their activity regardless 

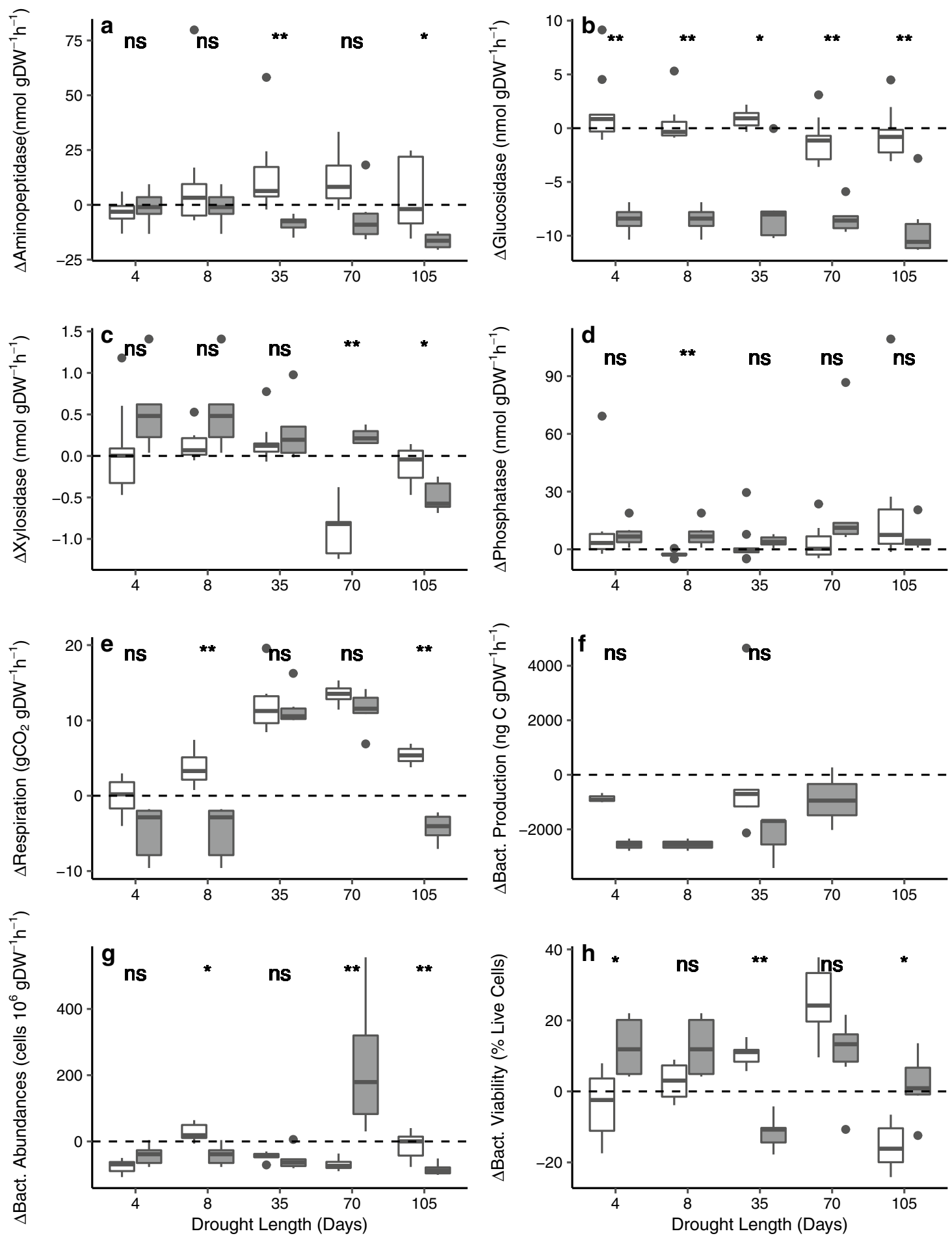

Drought Flume

Fig. 4 Effects of drought duration 7 days after rewetting on functional hyporheic variables. Presented are standardized values of the flumes that experienced drought 7 days after rewetting (white boxes) compared to the standardized values of the reference flume (gray boxes) at the same time. Significance indicators are for the comparison between the flume that experienced drought and corresponding reference flume ( $n s$ not significant, $* \mathrm{p} \leq 0.05, * * \mathrm{p} \leq 0.01, * * * \mathrm{p} \leq 0.001$ ). Note that the reference sample is the same for 4- and 8-days dry due to the sampling schedule 
of drought duration up to the 105 days tested. Likewise, we observed no effects of drought duration on the microbial processes after rewetting, contrary to our expectations. This indicated that during any of the tested drought periods, extreme desiccation did not occur to the extent that the habitat was modified or the community was harmed. Similarly, high moisture contents were observed in field studies of intermittent streams in Austria (Weigelhofer and Tritthart 2019), indicating that our experimental results reflect what occurs in natural systems. The high moisture content that sustained microbial functioning in the hyporheic zone during the drought phase probably also resulted in short recovery periods of the microbial processes after flow resumption (Marxsen et al. 2010).

The buffering effect of the hyporheic zone against desiccation stress was demonstrated by Gionchetta et al. (2019) in a laboratory experiment with sediment columns. These authors also attributed this effect to a higher remaining moisture content in the hyporheic zone compared to the surface. In their study, EEA and bacterial viability were significantly reduced in surface sediments $(0.5 \%$ remaining water content), but not in the hyporheic zone ( $2.5 \%$ water content). Sustained microbial processes (EEA in particular) at higher moisture content have also been observed in other experimental and field-studies (Oprei et al. 2019; Pohlon et al. 2013; Timoner et al. 2012), while lower moisture contents have been shown to lower intracellular water potential reducing microbial activities (i.e., EEA, bacterial abundances, viability, production; Amalfitano et al. 2008; Marxsen et al. 2010; Pohlon et al. 2013).

In addition to the buffering effect of the hyporheic zone, the high moisture content in our experiment can also be attributed to the temperate climate and the shaded location of the experimental flumes. Temperate streams often retain a higher moisture content during a dry phase than Mediterranean streams, even in the benthic zone, and the higher moisture content may allow for the protection of the stream biofilm communities (Amalfitano et al. 2008; Marxsen et al. 2010). Marxsen et al. (2010), for example, reported higher bacterial abundances in temperate stream sediments than in Mediterranean sediments after rewetting, suggesting an improved survival of bacteria during the drought phase. Febria et al. (2012) observed small effects of noflow conditions on hyporheic biofilms and speculated that the hyporheic zone may act as refuge for micro-organisms during droughts. Other factors for the preservation of the moisture content may be a high proportion of fine sediments and organic matter in the hyporheic zone (McKew et al. 2011). However, organic matter in our experiment was low $(0.35 \pm 0.15 \%$ per dry weight sediment $)$ but represents the average of hyporheic sediments in the region $(0.38 \pm 0.14 \%$ per dry weight sediment; average of five hyporheic sediments; Katrin Attermeyer (personal communication)).
Therefore, we assume that organic matter did not play a relevant role in keeping up the relatively high soil moisture in our drought flumes. As this is an experimental study, additional field studies are required to further relate the results of this study to natural streams, especially in temperate regions which have been largely neglected so far (Datry et al. 2017; others). This is particularly important considering the fact that, with decreasing summer precipitation due to climate change, temperate streams may be subject to enhanced, but infrequent summer droughts of variable length (Laaha et al. 2017; Van Loon et al. 2014; Teuling et al. 2013).

\section{Changes in flow regime can stimulate microbial processing}

Previous studies have found that droughts may transiently increase specific microbial processes, such as dissolved organic matter (DOM) decomposition and respiration (Harjung et al. 2019). In this study, we found indications that drying and rewetting may stimulate microbial mineralization in the immediate post-drought phase, (i.e. during the first week after rewetting). Pre- and post-drought glucosidase activities, for example, were similar in the drought flumes independent of drought duration, while they were decreased in the corresponding values of the reference flume throughout the entire experiment. Our findings are supported by Gionchetta et al. (2019), who also observed higher glucosidase activities in hyporheic samples that experienced drought compared to the wet control samples. In contrast, other sediment column studies showed lower or similar glucosidase activities in rewetted sediments compared to the control (surface samples, Gionchetta et al. 2019; Marxsen et al. 2010). Likewise, post-drought aminopeptidase activities increased with increasing drought duration compared to pre-drought values, while it decreased in the reference flume, indicating a possible stimulation of microbial mineralization by drying and re-wetting. This could be explained by hypoxic conditions in the wet reference subsurface, reducing EEA (Taylor et al. 2009).

We also observed slightly increased activities of aminopeptidase at the end of the drought period. This contrasts with similar studies that observed decreased peptidase activities during the dry phase (Pohlon et al. 2013; Timoner et al. 2012). Besides the maintenance of a high moisture content and, thus, an active microbial community, the increased sediment temperatures in our flumes may have boosted microbial mineralization, as enzyme activities are temperature sensitive (German et al. 2011; Koch et al. 2007; Sinsabaugh et al. 2008). Due to the unrestricted exposure of our flumes to natural summer air temperatures, drought flumes reached maximum sediment temperatures of $21{ }^{\circ} \mathrm{C}$ during the dry phase in summer. Aminopeptidase also showed increased activities in the mid-summer drought and rewetting samples 
(flumes with 35- and 70-day drought duration), exceeding those of the permanently flooded and, thus, colder reference flume (maximum $15{ }^{\circ} \mathrm{C}$ in mid-summer). Likewise, aminopeptidase activities were lower in the flume that experienced a 105-day drought, where sampling occurred already in late summer at lower temperatures. The temperature influence on EEA is supported by a similar mid-summer increase in the microbial respiration of the flumes that experienced 35- and 70-day drought. It is also important to note that the EEA incubations were done in the lab at a standardized temperature $\left(20^{\circ} \mathrm{C}\right)$ throughout the experiment. So, although temperatures were fluctuating naturally outside, the incubation may have masked higher differences in EEA. Air temperature fluctuations are generally dampened in the surface water and hyporheic zone under flow conditions (Arrigoni et al. 2008), an effect that is suspended in dry riverbeds (Supp. Fig. 2). Our results show that, if enough moisture is retained in the sediment during drought, the higher summer air temperatures can maintain or even increase microbial processes in hyporheic sediments of intermittent streams in the temperate zone. We thus suggest that hyporheic sediments can be sites of increased nutrient and carbon processing during droughts. Hence, with ongoing climate change accelerating droughts and air temperatures in the temperate zone, this effect will become more important and should be taken into consideration in the future.

Besides temperature effects, the increase in enzymatic activities during the dry phase could be also caused by methodological limitations with analyzing dry phase samples (Pohlon et al. 2013). Adding the artificial substrate to the sample simulates rewetting, which potentially breaks the polymeric matrix of the biofilm and can release enzymes otherwise bound in the biofilm (Pohlon et al. 2013). Therefore, dry phase samples could yield higher values for enzymatic activities than wet phase samples (Pohlon et al. 2013). In addition, studies have found enzymatic activities from stream sediments to be higher in undisturbed sediment cores than in sediment slurries (Marxsen and Fiebig 1993). However, despite noting these methodological difficulties, we argue that our approach appeared robust and that our results were at least reasonably consistent among experimental replicates of different flumes and sampling times.

Microbial respiration did not only increase in the flumes that experienced drought during mid-summer, but also in the reference flume. This indicates strong seasonal effects that superimpose the effects of drought during this period. Respiration is stimulated by temperature (Koch et al. 2007) and the highest values of respiration occurred in mid-summer (July and August), independent of whether flumes were dry or not. However, early (4d- and 8d- flumes) and late summer (90d-flume) samplings showed significantly higher respiration rates in the flumes that experienced drought than in the reference flume. This could be explained by the increased portion of viable prokaryotic cells in the flumes that experienced drought compared to the reference and the potential mobilization and/or leaching of dissolved organic matter due to rewetting, as was observed by other studies (Bernal et al. 2013; von Schiller et al. 2011; Shumilova et al. 2019). Other studies show that large respiration pulses after rewetting lead to higher $\mathrm{CO}_{2}$ emissions from intermittent streams and therefore can largely affect ecosystem functioning (Marcé et al. 2019; von Schiller et al. 2019, 2014). From our results, we conclude that drought may stimulate microbial activities after flow resumption as long as no-flow conditions are moderate and the community remains mainly intact. However, during summer increasing temperatures in the sediments may overlay the effects of drought for respiration and bacterial viability.

\section{Conclusion}

In conclusion, the high moisture content remaining in the hyporheic zone of the flumes allowed for the sustained microbial functioning during drought, regardless of drought duration. This can be attributed to cooler temperatures in temperate regions $\left(17.2{ }^{\circ} \mathrm{C}\right.$ average summer temperature in Lunz in 2019) and shading by riparian forests commonly present in Austria. The high moisture content prevented serious habitat and community changes on a local scale that the biofilm might have undergone during a more severe drought. Therefore, high remaining moisture content could increase the resilience of the microbial biofilm communities against drought events. However, changes in the hyporheic flow regime (flow cessation and resumption) may stimulate microbial processing at moderate drought conditions. This can be explained by the changes in nutrient and organic matter availability, due to the presence/absence of flowing water. Therefore, in regions where moderate drought occurs, more frequent drought events might have a greater impact than long uninterrupted dry periods.

Nevertheless, the role of the hyporheic zone as buffer against drought and the factors determining this buffer capacity, such as sediment characteristics and climatic regions, need to be analyzed in more detail. Further research is also needed, especially in temperate regions, to determine the ecological short- and long-term impacts of future water scarcity on stream ecosystems and develop sustainable management strategies to compensate climate change effects.

Supplementary Information The online version contains supplementary material available at https://doi.org/10.1007/s00027-021-00799-3.

Acknowledgements The study was funded by the City of Vienna, MA31-Wiener Wasser (MA31-985621/17). Additional financial support was provided by the Austrian Research Promotion Agency (FFG) within the program "FEMtech". We would like to thank Tania Sosa 
Jiron, Johanna Kraus, Sabrina Teufl, Lisa-Marie Ziegler, and Tz-Ching Yeh for assistance in the field and the lab. We would also like to thank Michael Mayr and Annette Puritscher for assistance in constructing the flumes.

Funding Open access funding provided by University of Natural Resources and Life Sciences Vienna (BOKU).

\section{Declarations}

Conflict of interest The authors have no conflicts of interest to declare that are relevant to the content of this article.

Open Access This article is licensed under a Creative Commons Attribution 4.0 International License, which permits use, sharing, adaptation, distribution and reproduction in any medium or format, as long as you give appropriate credit to the original author(s) and the source, provide a link to the Creative Commons licence, and indicate if changes were made. The images or other third party material in this article are included in the article's Creative Commons licence, unless indicated otherwise in a credit line to the material. If material is not included in the article's Creative Commons licence and your intended use is not permitted by statutory regulation or exceeds the permitted use, you will need to obtain permission directly from the copyright holder. To view a copy of this licence, visit http://creativecommons.org/licenses/by/4.0/.

\section{References}

Acuña V, Muñoz I, Giorgi A, Omella M, Sabater F, Sabater S (2005) Drought and postdrought recovery cycles in an intermittent Mediterranean stream: structural and functional aspects. J N Am Benthol Soc 24(4):919-933. https://doi.org/10.1899/04-078.1

Acuña V, Casellas M, Corcoll N, Timoner X, Sabater S (2015) Increasing extent of periods of no flow in intermittent waterways promotes heterotrophy. Freshw Biol 60(9):1810-1823. https://doi. org/10.1111/fwb.12612

Allen GH, Pavelsky TM (2018) Global extent of rivers and streams. Science 361(6402):585-588. https://doi.org/10.1126/science. aat0636

Amalfitano S, Fazi S, Zoppini A, Barra Caracciolo A, Grenni P, Puddu A (2008) Responses of benthic bacteria to experimental drying in sediments from Mediterranean temporary rivers. Microb Ecol 55(2):270-279. https://doi.org/10.1007/s00248-007-9274-6

Arce MI, von Schiller D, Bengtsson MM, Hinze C, Jung H, Alves RJE, Urich T, Singer G (2018) Drying and rainfall shape the structure and functioning of nitrifying microbial communities in riverbed sediments. Front Microbiol. https://doi.org/10.3389/fmicb.2018. 02794

Arias-Real R, Muñoz I, Gutierrez-Cánovas C, Granados V, LopezLaseras P, Menéndez M (2020) Subsurface zones in intermittent streams are hotspots of microbial decomposition during the nonflow period. Sci Total Environ 703:135485. https://doi.org/10. 1016/j.scitotenv.2019.135485

Arrigoni AS, Poole GC, Mertes LAK, O'Daniel SJ, Woessner WW, Thomas SA (2008) Buffered, lagged, or cooled? Disentangling hyporheic influences on temperature cycles in stream channels. Water Resour Res. https://doi.org/10.1029/2007WR006480

Battin TJ, Kaplan LA, Findlay S, Hopkinson CS, Marti E, Packman A, Newbold JD, Sabater F (2008) Biophysical controls on organic carbon fluxes in fluvial networks. Nat Geosci 1(2):95-100. https:// doi.org/10.1038/ngeo101
Battin TJ, Besemer K, Bengtsson MM, Romani AM, Packmann AI (2016) The ecology and biogeochemistry of stream biofilms. Nat Rev Microbiol 14(4):251-263. https://doi.org/10.1038/nrmicro. 2016.15

Bernal S, Von Schiller D, Sabater F, Martí E (2013) Hydrological extremes modulate nutrient dynamics in Mediterranean climate streams across different spatial scales. Hydrobiologia. https://doi. org/10.1007/s10750-012-1246-2

Boano F, Harvey JW, Marion A, Packman AI, Revelli R, Ridolfi L, Wörman A (2014) Hyporheic flow and transport processes: mechanisms, models, and biogeochemical implications. Rev Geophys 52(4):603-679. https://doi.org/10.1002/2012RG000417

Boodoo KS, Schelker J, Trauth N, Battin TJ, Schmidt C (2019) Sources and variability of $\mathrm{CO}_{2}$ in a prealpine stream gravel bar. Hydrol Process 33(17):2279-2299. https://doi.org/10.1002/hyp.13450

Boulton AJ, Findlay S, Marmonier P, Stanley EH, Valett HM (1998) The functional significance of the hyporheic zone in streams and rivers. Annu Rev Ecol Syst 29(1):59-81. https://doi.org/ 10.1146/annurev.ecolsys.29.1.59

Buesing N, Gessner MO (2003) Incorporation of radiolabeled leucine into protein to estimate bacterial production in plant litter, sediment, epiphytic biofilms, and water samples. Microb Ecol 45(3):291-301. https://doi.org/10.1007/s00248-002-2036-6

Burrows RM, Rutlidge H, Bond NR, Eberhard SM, Auhl A, Andersen MS, Valdez DG, Kennard MJ (2017) High rates of organic carbon processing in the hyporheic zone of intermittent streams. Sci Rep 7(1):1-11. https://doi.org/10.1038/s41598-017-12957-5

Cavanaugh JC, Richardson W, Strauss E, Bartsch LA (2006) Nitrogen dynamics in sediment during water level manipulation on the upper Mississippi River. River Res Appl 22:651-666. https://doi.org/10.1002/rra.926

Colls M, Timoner X, Font C, Sabater S, Acuña V (2019) Effects of duration, frequency, and severity of the non-flow period on stream biofilm metabolism. Ecosystems. https://doi.org/10. 1007/s10021-019-00345-1

Dahm CN, Baker MA, Moore DI, Thibault JR (2003) Coupled biogeochemical and hydrological responses of streams and rivers to drought. Freshw Biol 48(7):1219-1231. https://doi.org/10. 1046/j.1365-2427.2003.01082.x

Dai A (2013) Increasing drought under global warming in observations and models. Nat Clim Chang 3(1):52-58. https://doi.org/ $10.1038 /$ nclimate 1633

Danczak RE, Sawyer AH, Williams KH, Stegen JC, Hobson C, Wilkins MJ (2016) Seasonal hyporheic dynamics control coupled microbiology and geochemistry in Colorado River sediments. J Geophys Res Biogeosci 121(12):2976-2987. https:// doi.org/10.1002/2016JG003527

Datry T, Larned ST, Tockner K (2014) Intermittent rivers: a challenge for freshwater ecology. Bioscience 64(3):229-235. https:// doi.org/10.1093/biosci/bit027

Datry T, Bonada N, Boulton AJ (2017) Chapter 1-general introduction. In: Intermittent rivers and ephemeral streams. Academic Press, pp. 1-20, https://doi.org/10.1016/B978-0-12-803835-2. 00001-2

Dieterich M, Anderson NH (1998) Dynamics of abiotic parameters, solute removal and sediment retention in summer-dry headwater streams of western Oregon. Hydrobiologia 379(1-3):1-15. https://doi.org/10.1023/A:1003423016125

Drake TW, Raymond PA, Spencer RGM (2018) Terrestrial carbon inputs to inland waters: a current synthesis of estimates and uncertainty. Limnol Oceanogr Lett 3(3):132-142. https://doi. org/10.1002/lol2.10055

Duhamel S, Jacquet S (2006) Flow cytometric analysis of bacteriaand virus-like particles in lake sediments. J Microbiol Methods 64(3):316-332. https://doi.org/10.1016/j.mimet.2005.05.008 
Dunn OJ (1961) Multiple comparisons among means. J Am Stat Assoc 56(293):52-64. https://doi.org/10.1080/01621459.1961. 10482090

Fasching C, Ulseth AJ, Schelker J, Steniczka G, Battin TJ (2016) Hydrology controls dissolved organic matter export and composition in an Alpine stream and its hyporheic zone. Limnol Oceanogr 61(2):558-571. https://doi.org/10.1002/lno.10232

Febria CM, Beddoes P, Fulthorpe RR, Williams DD (2012) Bacterial community dynamics in the hyporheic zone of an intermittent stream. ISME J 6(5):1078-1088. https://doi.org/10.1038/ismej. 2011.173

German DP, Weintraub MN, Grandy AS, Lauber CL, Rinkes ZL, Allison SD (2011) Optimization of hydrolytic and oxidative enzyme methods for ecosystem studies. Soil Biol Biochem 43(7):13871397. https://doi.org/10.1016/j.soilbio.2011.03.017

Gionchetta G, Oliva F, Menéndez M, Laseras PL, Romaní AM (2019) Key role of streambed moisture and flash storms for microbial resistance and resilience to long-term drought. Freshw Biol 64(2):306-322. https://doi.org/10.1111/fwb.13218

Gobiet A, Kotlarski S, Beniston M, Heinrich G, Rajczak J, Stoffel M (2014) 21st century climate change in the European Alpsa review. Sci Total Environ 493:1138-1151. https://doi.org/10. 1016/j.scitotenv.2013.07.050

Grimm V, Wissel C (1997) Babel, or the ecological stability discussions: an inventory and analysis of terminology and a guide for avoiding confusion. Oecologia 109(3):323-334. https://doi.org/ $10.1007 / \mathrm{s} 004420050090$

Harjung A, Perujo N, Butturini A, Romaní AM, Sabater F (2019) Responses of microbial activity in hyporheic pore water to biogeochemical changes in a drying headwater stream. Freshw Biol 64(4):735-749. https://doi.org/10.1111/fwb.13258

Holling CS (1973) Resilience and stability of ecological systems. Annu Rev Ecol Syst 4(1):1-23. https://doi.org/10.1146/annurev.es.04. 110173.000245

IPCC (2013) Fifth Assessment Report-Climate Change 2013. Retrieved July 3, 2018, from http://www.ipcc.ch/report/ar5/wg1/

Kirchman D (2001) Measuring bacterial biomass production and growth rates from leucine incorporation in natural aquatic environments. In: Methods in microbiology, vol 30. Academic Press, pp. 227-237, https://doi.org/10.1016/S0580-9517(01)30047-8

Koch O, Tscherko D, Kandeler E (2007) Temperature sensitivity of microbial respiration, nitrogen mineralization, and potential soil enzyme activities in organic alpine soils. Glob Biogeochem Cycles. https://doi.org/10.1029/2007GB002983

Laaha G, Gauster T, Tallaksen LM, Vidal J-P, Stahl K, Prudhomme C, Heudorfer B, Vlnas R, Ionita M, Van Lanen HAJ, Adler M-J, Caillouet L, Delus C, Fendekova M, Gailliez S, Hannaford J, Kingston D, Van Loon AF, Mediero L, Wong WK (2017) The European 2015 drought from a hydrological perspective. Hydrol Earth Syst Sci 21(6):3001-3024. https://doi.org/10.5194/hess-21-3001-2017

Larned ST, Datry T, Arscott DB, Tockner K (2018) Emerging concepts in temporary-river ecology-LARNED-2010-Freshwater Biology_Wiley Online Library. Retrieved July 3, 2018, from https:// onlinelibrary.wiley.com/doi/abs/https://doi.org/10.1111/j.13652427.2009.02322.x

Leff L, Gray JBV, Martí E, Merbt SN, Romaní AM (2016) Aquatic biofilms and biogeochemical processes. In: Aquatic biofilms: ecology, water quality and wastewater treatment. Caister Academic Press, pp 89-108. https://doi.org/10.21775/9781910190173.05

Mann HB, Whitney DR (1947) On a test of whether one of two random variables is stochastically larger than the other. Ann Math Stat 18(1):50-60

Marcé R, Obrador B, Gómez-Gener L, Catalán N, Koschorreck M, Arce MI, Singer G, von Schiller D (2019) Emissions from dry inland waters are a blind spot in the global carbon cycle. Earth Sci Rev 188:240-248. https://doi.org/10.1016/j.earscirev.2018.11.012
Marxsen J, Fiebig DM (1993) Use of perfused cores for evaluating extracellular enzyme activity in stream-bed sediments. FEMS Microbiol Ecol 13(1):1-11. https://doi.org/10.1111/j.1574-6941. 1993.tb00045.x

Marxsen J, Zoppini A, Wilczek S (2010) Microbial communities in streambed sediments recovering from desiccation. FEMS Microbiol Ecol 71(3):374-386. https://doi.org/10.1111/j.1574-6941. 2009.00819.x

McClain ME, Boyer EW, Dent CL, Gergel SE, Grimm NB, Groffman PM, Hart SC, Harvey JW, Johnston CA, Mayorga E, McDowell WH, Pinay G (2003) Biogeochemical hot spots and hot moments at the interface of terrestrial and aquatic ecosystems. Ecosystems 6(4):301-312. https://doi.org/10.1007/s10021-003-0161-9

McKew BA, Taylor JD, McGenity TJ, Underwood GJC (2011) Resistance and resilience of benthic biofilm communities from a temperate saltmarsh to desiccation and rewetting. ISME J 5(1):30-41. https://doi.org/10.1038/ismej.2010.91

Oprei A, Zlatanović S, Mutz M (2019) Grazers superimpose humidity effect on stream biofilm resistance and resilience to dryrewet stress. Sci Total Environ 659:841-850. https://doi.org/ 10.1016/j.scitotenv.2018.12.316

Pohlon E, Fandino AO, Marxsen J (2013) Bacterial community composition and extracellular enzyme activity in temperate streambed sediment during drying and rewetting. PLoS ONE 8(12):e83365. https://doi.org/10.1371/journal.pone.0083365

Pusch M, Fiebig D, Brettar I, Eisenmann H, Ellis BK, Kaplan LA, Lock MA, Naegeli MW, Traunspurger W (1998) The role of micro-organisms in the ecological connectivity of running waters. Freshw Biol 40(3):453-495. https://doi.org/10.1046/j. 1365-2427.1998.00372.x

R: The R Project for Statistical Computing (2020) Retrieved April 6, 2020, from https://www.r-project.org/

Romaní AM, Sabater S (2001) Structure and activity of rock and sand biofilms in a mediterranean stream. Ecology 82(11):32323245. https://doi.org/10.1890/0012-9658(2001)082[3232: SAAORA]2.0.CO;2

Sabater S, Tockner K (2009) Effects of Hydrologic Alterations on the Ecological Quality of River Ecosystems, pp 15-39. https:// doi.org/10.1007/698_2009_24

Sabater S, Timoner X, Borrego C, Acuña V (2016) Stream biofilm responses to flow intermittency: from cells to ecosystems. Front Environ Sci. https://doi.org/10.3389/fenvs.2016.00014

Shumilova O, Zak D, Datry T, von Schiller D, Corti R, Foulquier A, Obrador B, Tockner K, Altermatt F, Arce MI, Arnon S, Banas $\mathrm{D}$, Banegas-Medina A, Beller E, Blanchette ML, BlancoLibreros JF, Blessing J, Boëchat IG, Boersma K, Zarfl C (2019) Simulating rewetting events in intermittent rivers and ephemeral streams: a global analysis of leached nutrients and organic matter. Glob Change Biol. https://doi.org/10.1111/gcb.14537

Simon M, Azam F (1989) Protein content and protein synthesis rates of planktonic marine bacteria. Mar Ecol Prog Ser. https://doi. org/10.3354/meps051201

Sinsabaugh RL, Lauber CL, Weintraub MN, Ahmed B, Allison SD, Crenshaw C, Contosta AR, Cusack D, Frey S, Gallo ME, Gartner TB, Hobbie SE, Holland K, Keeler BL, Powers JS, Stursova M, Takacs-Vesbach C, Waldrop MP, Wallenstein MD, Zeglin LH (2008) Stoichiometry of soil enzyme activity at global scale. Ecol Lett 11(11):1252-1264. https://doi.org/10. 1111/j.1461-0248.2008.01245.x

Stubbington R, England J, Wood PJ, Sefton CEM (2017) Temporary streams in temperate zones: recognizing, monitoring and restoring transitional aquatic-terrestrial ecosystems. WIREs Water 4(4):e1223. https://doi.org/10.1002/wat2.1223

Taylor GT, Thunell R, Varela R, Benitez-Nelson C, Scranton MI (2009) Hydrolytic ectoenzyme activity associated with 
suspended and sinking organic particles within the anoxic Cariaco Basin. Deep Sea Res Part I: Oceanogr Res Pap 56(8):1266-1283

Teuling AJ, van Loon AF, Seneviratne SI, Lehner I, Aubinet M, Heinesch B, Bernhofer C, Grünwald T, Prasse H, Spank U (2013) Evapotranspiration amplifies European summer drought. Geophys Res Lett 40(10):2071-2075. https://doi.org/10.1002/ grl.50495

Timoner X, Acuña V, Schiller DV, Sabater S (2012) Functional responses of stream biofilms to flow cessation, desiccation and rewetting. Freshw Biol 57(8):1565-1578. https://doi.org/10. 1111/j.1365-2427.2012.02818.x

Tooth S (2000) Process, form and change in dryland rivers: a review of recent research. Earth Sci Rev 51(1):67-107. https://doi.org/ 10.1016/S0012-8252(00)00014-3

Uehlinger U (2000) Resistance and resilience of ecosystem metabolism in a flood-prone river system. Freshw Biol 45(3):319-332. https:// doi.org/10.1111/j.1365-2427.2000.00620.x

van Loon AF, Tijdeman E, Wanders N, van Lanen HAJ, Teuling AJ, Uijlenhoet R (2014) How climate seasonality modifies drought duration and deficit. J Geophys Res Atmos 119(8):4640-4656. https://doi.org/10.1002/2013JD020383

Vazquez E, Amalfitano S, Fazi S, Butturini A (2011) Dissolved organic matter composition in a fragmented Mediterranean fluvial system under severe drought conditions. Biogeochemistry 102(1):59-72. https://doi.org/10.1007/s10533-010-9421-x

von Schiller D, Acuña V, Graeber D, Martí E, Ribot M, Sabater S, Timoner X, Tockner K (2011) Contraction, fragmentation and expansion dynamics determine nutrient availability in a Mediterranean forest stream. Aquat Sci 73(4):485. https://doi.org/10.1007/ s00027-011-0195-6

von Schiller D, Marcé R, Obrador B, Gómez-Gener L, Casas-Ruiz J, Acuña V, Koschorreck M (2014) Carbon dioxide emissions from dry watercourses. Inland Waters 4(4):377-382. https://doi.org/10. 5268/IW-4.4.746

von Schiller D, Datry T, Corti R, Foulquier A, Tockner K, Marcé R, García-Baquero G, Odriozola I, Obrador B, Elosegi A, Mendoza-Lera C, Gessner MO, Stubbington R, Albariño R, Allen DC, Altermatt F, Arce MI, Arnon S, Banas D, Zoppini A (2019) Sediment respiration pulses in intermittent rivers and ephemeral streams. Global Biogeochem Cycles 33(10):1251-1263. https:// doi.org/10.1029/2019GB006276

Weigelhofer G, Tritthart M (2019) Austrocknung von Bächen-eine Gefahr für die Wasserqualität? Oesterr Wasser Abfallwirtsch 71(7):385-391. https://doi.org/10.1007/s00506-019-0580-2

Ylla I, Sanpera-Calbet I, Vázquez E, Romaní AM, Muñoz I, Butturini A, Sabater S (2010) Organic matter availability during pre- and post-drought periods in a Mediterranean stream. In: Stevenson RJ, Sabater S (eds) Global change and river ecosystems-implications for structure, function and ecosystem services. Springer Netherlands, pp 217-232. https://doi.org/10.1007/978-94-0070608-8_15

Zlatanović S, Fabian J, Premke K, Mutz M (2018) Shading and sediment structure effects on stream metabolism resistance and resilience to infrequent droughts. Sci Total Environ 621:1233-1242. https://doi.org/10.1016/j.scitotenv.2017.10.105

Zoppini A, Marxsen J (2010) Importance of extracellular enzymes for biogeochemical processes in temporary river sediments during fluctuating dry-wet conditions. Soil Enzymol. https://doi.org/10. 1007/978-3-642-14225-3_6

Publisher's Note Springer Nature remains neutral with regard to jurisdictional claims in published maps and institutional affiliations. 